\title{
Estriol review: Clinical applications and potential biomedical importance
}

\author{
Nadia Falah ${ }^{1}$, John Torday ${ }^{2}$, Sara K. Quinney ${ }^{1}$ and David M. Haas ${ }^{1}$ \\ ${ }^{1}$ Department of OB/GYN, Indiana University School of Medicine, USA \\ ${ }^{2}$ Department of Pediatrics, David Geffen School of Medicine at UCLA, USA
}

\begin{abstract}
The clinical relevance and biological significance of estriol (E3), one of the three major human estrogens, are presented in this review. While initially having limited therapeutic indications, research has demonstrated E3's utility as a biomarker to screen for disease, to test for placental function, and as a novel drug for human use. Current research is further exploring E3's potential as a diagnostic and therapeutic tool.
\end{abstract}

\section{Introduction}

Estrogens are natural endogenous hormones with various physiological actions. Estriol (E3) is a dominant estrogen during pregnancy, and is secreted mainly by the placenta [1]. E3 tests of placental or feto-placental function are widely used in high-risk pregnancies to predict adverse fetal outcome [2]. It is also used as a part of hormonal replacement therapy in the United Kingdom and European Union but is used less due to safety concerns in the US and Canada [3]. The objective of this review is to address the biological and pharmacological properties and the clinical utility of E3.

\section{Formation and metabolism}

Estriol (3,16,17 trihydroxy 1,3,5-oestriene, E3) was first isolated by Edward Adelbert Doisy in 1923 at St. Louis University. Termed theelin by Doisy, E3 was isolated along with two other estrogenic female sex hormones, now known as estrone and estradiol from urine obtained from pregnant women [4]. E3, like the other two estrogens is an 18 carbon steroid $\left(\mathrm{C}_{18} \mathrm{H}_{24} \mathrm{O}_{3}\right)$, but it is distinguished by being 16-hydroxylated [5] (Figure 1).

E3 is the weakest of the three major estrogens with regards to estrogen receptor binding. In non-pregnant premenopausal women,

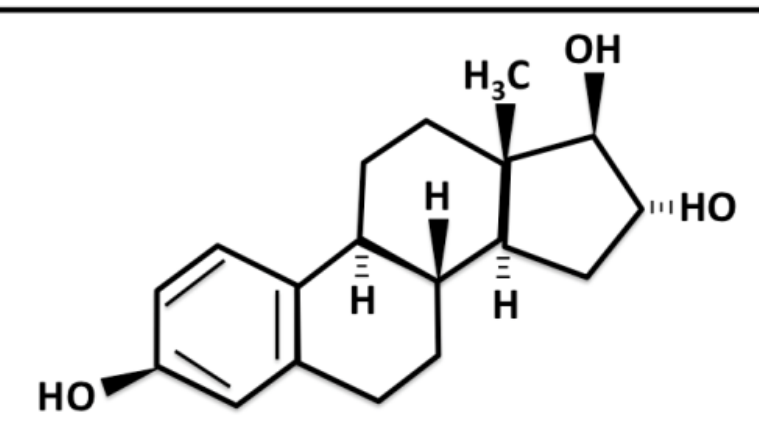

Figure 1. The chemical structure of estriol: $\mathrm{C}_{18} \mathrm{H}_{24} \mathrm{O}_{3}$.
E3 arises mainly as a product of the metabolism of estradiol and estronein the liver. In small quantities it is also synthesized in the ovary by the inner sheath and granular cells of ovarian follicles and the corpus luteum $[6,7]$.

E3 of fetal origin originates exclusively from the 16-hydroxylation of either dehydroepiandrosterone (DHEA) or DHEA sulfate (DHEAS) in the fetal liver, and is metabolized by steroid sulfatase in the placenta. DHEA undergoes aromatization by the aromatase enzyme (CYP19) in the syncytiotrophoblasts of the placenta as blood flows from the conceptus to the mother (Figure 2). Due to the hemochorial nature of the placenta, more than $90 \%$ of estriol formed in the syncytiotrophoblast enters the maternal circulation [8].

Once in the maternal circulation, E3 is transported to the liver. The maternal liver rapidly conjugates E3 by glucuronyltransferase enzyme to make it more water soluble for urinary excretion. About 80-90 percent of E3 circulates as the glucuronide conjugate, and 1015 percent as unconjugated E3 (uE3) [6,9]. The maternal half-life of $\mathrm{uE} 3$ is 20 to 30 minutes. In pregnancy, the average concentration of urinary E3 increases gradually until the $12^{\text {th }}$ week of gestation, and then increases more rapidly until term, with characteristic surge preceding the onset of labor [10].

Estriol urinary excretion in non-pregnant women ranges between $0.02-0.1 \mathrm{mg} / 24 \mathrm{hrs}$, while in near-term pregnant women the range is between $50-150 \mathrm{mg} / 24 \mathrm{hrs}$ [11]. The plasma concentrations of estriol and other estrogens increase as human pregnancy progresses [1] (Figure 3). While E3 is produced by conjugation of uE3 when in maternal circulation, uE3 is produced almost entirely by the fetoplacental unit, and therefore is a more sensitive indicator of fetal health [12]

Correspondence to: Nadia Falah, Department of OB/GYN, Indiana University School of Medicine, 550 North University Blvd, UH 2440, Indianapolis, IN 46202, USA, Tel: (317) 880-3960; Fax: (317) 880-0570; E-mail: falahnadia@gmail.com

Key words: estriol, pregnancy, biomarker, estrogen

Received: April 10, 2015; Accepted: May 20, 2015; Published: May 29, 2015 
1960's [19], and are a component of the current serum marker screens for fetal anomalies.

\section{Estriol testing in pregnancy}

E3 has been utilized in screening obstetric populations for adverse pregnancy outcomes since 1960 [20]. E3 can be measured in maternal blood or urine, and is used as a marker for prenatal biochemical screening for fetal health and well being (Table 1), and aids in the diagnosis of multiple congenital anomalies.

While maternal serum $\mathrm{uE} 3$ as a single marker has poor predictive power, its inclusion improves the predictive value of maternal age and AFP in screening for Down syndrome [21]. uE3 is therefore a component of both the triple and quadruple serum marker antenatal screening tests for chromosomal and congenital anomalies [22]. The triple screen measures serum concentrations of alfa fetoprotein (AFP), human chorionic gonadotropin (hCG) and unconjugated E3, while the quad screen also includes pregnancy-associated plasma protein A (PAP-A). These tests may be performed in the early $2^{\text {nd }}$ trimester to detect aneuploidy and other fetal anomalies, such as neural tube defects [23]. The levels of uE3 are abnormally low in trisomy 21 (Down syndrome) [22,24] and trisomy 18 (Edward's syndrome) [25].

Maternal serum uE3 decreases during the second trimester of pregnancy in cases of fetal growth restriction [26]. Serial urine and serum uE3 measurements less than 0.75 multiples of the median between 30 and 42 weeks of gestation are associated with significant fetal growth restriction [27]. Mothers who carry growth-restricted fetuses have serum E3 levels that are about half the normal level [2830]. In addition, association studies have correlated low early $2^{\text {nd }}$ trimester E3 levels with fetal demise [31], and low $1^{\text {st }}$ trimester levels of $\mathrm{uE} 3$ are associated with pregnancy loss [32,33].

E3 has also been studied in association with other perinatal clinical applications. E3 rises approximately 4 weeks before the onset of labor. A high level of uE3 or a sudden increase in maternal uE3 levels are potential markers of impending labor [34], and multiple studies have examined the potential use of $\mathrm{uE} 3$ as a biomarker for predicting the onset of labor [35-37]. However, it has not been found to be a reliable marker for either prediction of the onset of labor or when to induce labor. A recent resurgence of interest has occurred in looking at E3 as a marker for preterm birth [38]. Research continues regarding the

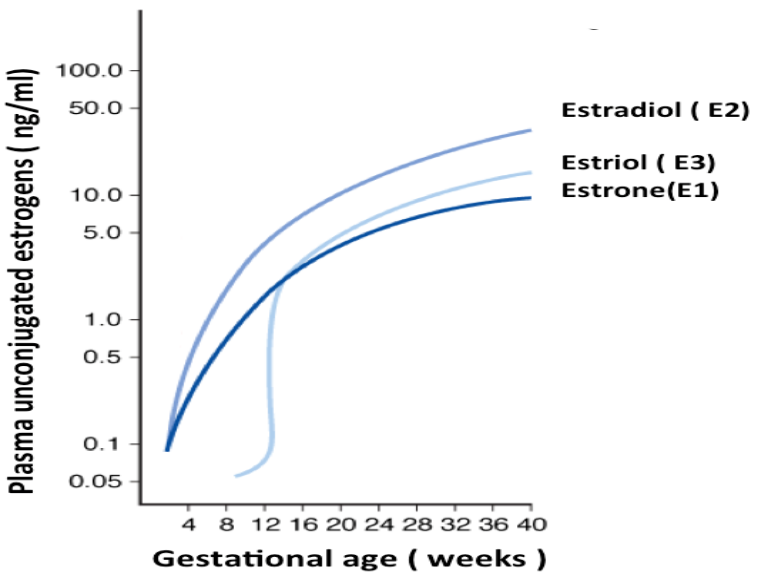

Adapted from Figure 3-28 from Cunningham FG, Leveno KJ, Bloom SL, Hauth JC, Rouse DJ, Spong CY: Williams Obstetrics, $23^{\text {rd }}$ edition.

Figure 3. Plasma levels of unconjugated estrone, estradiol and estriolin human pregnancy. 
Table 1. The use of uE3 in clinical orprenatal diagnosis [68].

\begin{tabular}{|l|l|}
\hline Serum $<\mathbf{0 . 3} \times$ of the gestational age median* & $\begin{array}{l}\text { Serum uE3 }>\mathbf{3} \times \text { of gestational age mean } \\
\text { Or with an absolute value of }>\mathbf{2 . 1} \mathbf{~ n g} / \mathbf{m l}\end{array}$ \\
\hline Trisomy 18 and 21 ( part of Quad test) & Pending labor \\
\hline Fetal demise & Congenital adrenal hyperplasia \\
\hline Smith-Lemli-Opitz syndrome & \\
\hline X-linked icthyosis ( contiguous gene syndrome ) & \\
\hline Aromatase deficiency & \\
\hline Primary or secondary fetal adrenal insufficiency & \\
\hline
\end{tabular}

*In women who otherwise screen negative in the quad test.

role of E3 as a biomarker for the fetal response to various pregnancy conditions [39-41].

\section{Therapeutic uses}

In a randomized, placebo-controlled trial, treatment of postmenopausal women with daily E3 $(2-4 \mathrm{mg})$ demonstrated a significant ability to treat hot flashes $[42,43]$. Also, E3 reduced urinary urgency and leakage [44], and the frequency of urinary tract infections [45-47]. In addition, E3 promotes restoration of normal vaginal flora, and improves vaginal atrophy in menopausal women without associated endometrial side effects $[48,49]$. In addition, E3 used in hormone replacement therapy regimens has been noted to improve bone density [50,51] without negatively impacting lipids [52-54], liver function [55,56], breast tissue [57,58], or blood pressure [42].

Interestingly, E3 treatment has been found to improve clinical symptoms of multiple sclerosis and to reduce cerebral lesions. These same cerebral lesions increased in size when treatment was stopped and decreased when treatment was restarted [59]. Another clinical trial in males found that, compared to placebo, E3 ameliorated symptoms of encephalomyelitis, a disease that shares a lot of characteristics with multiple sclerosis [60]. The proposed mechanism is that proinflammatory cytokine production is decreased by E3 treatment, while antibodies to the autoantigen responsible for the demyelination or destruction of the nerves are increased [60,61]. Another suggested mechanism is that at a concentration consistent with late pregnancy, E3 inhibits nitric oxide production by microglial cells activated in response to inflammatory cytokines [62]. Research findings have also suggested that E3 decreases $\mathrm{T}$ cell expression of matrix metalloproteinase-9, which is responsible for the demyelination process [63]. Thus, E3 may contribute to treatment of some inflammatory or neurological conditions.

\section{Estriol measurements}

Because of fluctuating and pulsatile E3 secretion, diurnal variation, and its short half-life, testing for E3 at a single time point by serum or saliva is imprecise. The most accurate way to assess estriol is by 24 -hour urine collection [64]. However urine collections for this purpose are inconvenient. Although serum and plasma E3 have been widely used to test for E3, a venipuncture for blood assays requires clinic visits, and can be painful and stressful. Salivary E3 has also been an enticing target for biomarker research in pregnancy. Dullien et al. emphasized the biological utility of measuring salivary E3 concentrations in pregnant women. Plasma E3 circulates in a protein-bound state [65], whereas salivary E3 is a measure of $\mathrm{uE} 3$, which is the biologically active fraction of the circulating hormone. The overall advantages of using salivary versus serum E3 are numerous: saliva can be obtained noninvasively, is stable during transport, and E3 measurements in saliva are highly reproducible $[66,67]$.

\section{Summary}

Estriol is a mainstay of current strategies in determining fetal anomalies through maternal serum screening. It is being used as an off-label component of therapies to treat menopausal symptoms as well. Although estriolis a component of several bio-identical hormone replacement therapy formulations, neither the FDA nor Health Canada approves or regulates these therapies. There are also studies currently underway to test for the efficacy of this molecule as a marker for various fetal responses to pregnancy conditions. Estriol may be important for a myriad of diagnostic, screening, and therapeutic uses.

\section{References}

1. Levitz M, Young BK (1977) Estrogens in pregnancy. Vitam Horm 35: 109-147. [Crossref]

2. Lindberg BS, Johansson ED, Nilsson BA (1974) Plasma levels of nonconjugated oestradiol-17beta and oestriol in high risk pregnancies. Acta Obstet Gynecol Scand 32: 37-51. [Crossref]

3. (2010) Bioidentical hormones. Med Lett Drugs Ther 52: 43-44. [Crossref]

4. Thayer LL, Edward A (1931) Doisy Characterization of Theelol. The Journal of biological Chemistry: 10

5. Oakey RE (1970) The progressive increase in estrogen production in human pregnancy: an appraisal of the factors responsible. Vitam Horm 28: 1-36. [Crossref]

6. Miller WL, Auchus RJ (2011) The molecular biology, biochemistry, and physiology of human steroidogenesis and its disorders. Endocr Rev 32: 81-151. [Crossref]

7. Fritz LS (2012) Clinical Gynecologic Endocrinology and Infertility. (8th edn) Lippincott Williams \& Wilkins.

8. Thomas MP, Potter BV (2013) The structural biology of oestrogen metabolism. $J$ Steroid Biochem Mol Biol 137: 27-49. [Crossref]

9. Gorbach SL, Goldin BR (1987) Diet and the excretion and enterohepatic cycling of estrogens. Prev Med 16: 525-531. [Crossref]

10. Darne J, McGarrigle HH, Lachelin GC (1987) Saliva oestriol, oestradiol, oestrone and progesterone levels in pregnancy: spontaneous labour at term is preceded by a rise in the saliva oestriol:progesterone ratio. Br J Obstet Gynaecol 94: 227-235. [Crossref]

11. Cunningham FG, Bloom SL, Hauth JC, Gilstrap LC III, Wenstrom KD (2007) Maternal Physiology. In Williams Obstetrics. (22 $2^{\text {nd }}$ edn). McGraw-Hill Publications.

12. Keren DF, Canick JA, Johnson MZ, Schaldenbrand JD, Haning RV, et al. (1995) Low maternal serum unconjugated estriol during prenatal screening as an indication of placental steroid sulfatase deficiency and X-linked ichthyosis. Am J Clin Pathol 103: 400-403. [Crossref]

13. Cohen SL (1985) A function for estriol during human pregnancy--a hypothesis. Clin Biochem 18: 85-87. [Crossref]

14. Reyes-Romero MA (2001) The physiological role of estriol during human fetal development is to act as antioxidant at lipophilic milieus of the central nervous system. Med Hypotheses 56: 107-109. [Crossref]

15. Watson CS, Jeng YJ, Kochukov MY (2008) Nongenomic actions of estradiol compared with estrone and estriol in pituitary tumor cell signaling and proliferation. FASEB J 22: 3328-3336. [Crossref]

16. Kreitmann B, Faye JC, Derache B, Bayard F (1979) Unequal binding of estrogens in human endometrium. J Steroid Biochem 11: 1253-1258. [Crossref] 
17. Tzingounis VA, Aksu MF, Greenblatt RB (1978) Estriol in the management of the menopause. JAMA 239: 1638-1641. [Crossref]

18. Gitsch E, Janisch H, Spona J (1980) HPL and estriol serum levels of placental perfusion as indexes of placental function in EPH gestosis and placental insufficiency. Gynecol Obstet Invest 11: 102-112. [Crossref]

19. Bashore RA, Westlake JR (1977) Plasma unconjugated estriol values in high-risk pregnancy. Am J Obstet Gynecol 128: 371-380. [Crossref]

20. Reis FM, D'Antona D, Petraglia F (2002) Predictive value of hormone measurements in maternal and fetal complications of pregnancy. Endocr Rev 23: 230-257. [Crossref]

21. Wald NJ, Cuckle HS, Densem JW, Nanchahal K, Canick JA, et al. (1988) Materna serum unconjugated oestriol as an antenatal screening test for Down's syndrome. $\mathrm{BrJ}$ Obstet Gynaecol 95: 334-341. [Crossref]

22. Malone FD, Canick JA, Ball RH, Nyberg DA, Comstock CH, et al. (2005) Firsttrimester or second-trimester screening, or both, for Down's syndrome. $N$ Engl J Med 353: 2001-2011. [Crossref]

23. Wald NJ, Watt HC, Hackshaw AK (1999) Integrated screening for Down's syndrome on the basis of tests performed during the first and second trimesters. $N$ Engl $J$ Med 341: 461-467. [Crossref]

24. Wald NJ (2004) First-trimester screening for Down's syndrome. N Engl J Med 350: 619-621.

25. Wapner R, Thom E, Simpson JL, Pergament E, Silver R, et al. (2003) First-trimester screening for trisomies 21 and 18. N Engl J Med 349: 1405-1413. [Crossref]

26. Kim SY, Kim SK, Lee JS, Kim IK, Lee K (2000) The prediction of adverse pregnancy outcome using low unconjugated estriol in the second trimester of pregnancy without risk of Down's syndrome. Yonsei Med J 41: 226-229. [Crossref]

27. Aickin DR, Duff GB, Evans JJ, Legge M (1983) Antenatal biochemical screening to predict low birthweight infants. Br J Obstet Gynaecol 90: 129-133. [Crossref]

28. Reynolds JW, Barnhart BJ, Carlson CV (1986) Feto-placental steroid metabolism in growth retarded human fetuses. Pediatr Res 20: 166-168. [Crossref]

29. Kowalczyk TD, Cabaniss ML, Cusmano L (1998) Association of low unconjugated estriol in the second trimester and adverse pregnancy outcome. Obstet Gynecol 91: 396-400. [Crossref]

30. Yaron Y, Cherry M, Kramer RL, O’Brien JE, Hallak M, et al. (1999) Second-trimester maternal serum marker screening: maternal serum alpha-fetoprotein, beta-human chorionic gonadotropin, estriol, and their various combinations as predictors of pregnancy outcome. Am J Obstet Gynecol 181: 968-974. [Crossref]

31. Huang T, Owolabi T, Summers AM, Meier C, Wyatt PR (2005) The identification of risk of spontaneous fetal loss through second-trimester maternal serum screening. Am J Obstet Gynecol 193: 395-403. [Crossref]

32. Melis GB, Strigini F, Fruzzetti F, Paoletti AM, Battistelli P, et al. (1984) Ultrasound and estradiol plasma levels in threatened abortion. Acta Eur Fertil 15: 287-294. [Crossref]

33. Dessaive R, de Hertogh R, Thomas K (1982) Correlation between hormonal levels and ultrasound in patients with threatened abortion. Gynecol Obstet Invest 14: 65-78. [Crossref]

34. Hee L (2011) Likelihood ratios for the prediction of preterm delivery with biomarkers. Acta Obstet Gynecol Scand 90: 1189-1199. [Crossref]

35. Huang T, Hoffman B, Meschino W, Kingdom J, Okun N (2010) Prediction of adverse pregnancy outcomes by combinations of first and second trimester biochemistry markers used in the routine prenatal screening of Down syndrome. Prenat Diagn 30: 471-477. [Crossref]

36. Smith R, Smith JI, Shen X, Engel PJ, Bowman ME, et al. (2009) Patterns of plasma corticotropin-releasing hormone, progesterone, estradiol, and estriol change and the onset of human labor. J Clin Endocrinol Metab 94: 2066-2074. [Crossref]

37. Yeast JD, Lu G (2007) Biochemical markers for the prediction of preterm delivery. Clin Perinatol 34: 573-586, vi. [Crossref]

38. Olsen RN, Dunsmoor-Su R, Capurro D, McMahon K, Gravett MG (2013) Correlation between spontaneous preterm birth and mid-trimester maternal serum estriol. J Matern Fetal Neonatal Med 27: 376-380. [Crossref]

39. Tongprasert F, Srisupundit K, Luewan S, Tongsong T (2013) Second trimester maternal serum markers and a predictive model for predicting fetal hemoglobin Bart's disease. $J$ Matern Fetal Neonatal Med 26: 146-149. [Crossref]

40. Haas D, Haege G, Hoffmann GF, Burgard P (2013) Prenatal presentation and diagnostic evaluation of suspected Smith-Lemli-Opitz (RSH) syndrome. Am J Med Genet A 161A: 1008-1011. [Crossref]

41. Bestwick JP, Huttly WJ, Wald NJ (2012) Unconjugated estriol values between 14 and 22 weeks of gestation in relation to prenatal screening for Down syndrome. Prenat Diagn 32: 299-301. [Crossref]

42. Takahashi K, Okada M, Ozaki T, Kurioka H, Manabe A, et al. (2000) Safety and efficacy of oestriol for symptoms of natural or surgically induced menopause. Hum Reprod 15: 1028-1036. [Crossref]

43. Speroff L (2005) Alternative therapies for postmenopausal women. Int J Fertil Womens Med 50: 101-114. [Crossref]

44. Ishiko O, Hirai K, Sumi T, Tatsuta I, Ogita S (2001) Hormone replacement therapy plus pelvic floor muscle exercise for postmenopausal stress incontinence. A randomized, controlled trial. J Reprod Med 46: 213-220. [Crossref]

45. Pinggera GM, Feuchtner G, Frauscher F, Rehder P, Strasser H, et al. (2005) Effects of local estrogen therapy on recurrent urinary tract infections in young females under oral contraceptives. Eur Urol 47: 243-249. [Crossref]

46. McCully KS, Jackson S (2004) Hormone replacement therapy and the bladder. $\mathrm{J} \mathrm{Br}$ Menopause Soc 10: 30-32. [Crossref]

47. Raz R (2001) Postmenopausal women with recurrent UTI. Int J Antimicrob Agents 17 269-271. [Crossref]

48. Manonai J, Theppisai U (2001) Effect of oral estriol on urogenital symptoms, vaginal cytology, and plasma hormone level in postmenopausal women. J Med Assoc Thai 84: 539-544. [Crossref]

49. Yoshimura T, Okamura H (2001) Short term oral estriol treatment restores normal premenopausal vaginal flora to elderly women. Maturitas 39: 253-257. [Crossref]

50. Hayashi T, Ito I, Kano H, Endo H, Iguchi A (2000) Estriol (E3) replacement improves endothelial function and bone mineral density in very elderly women. $J$ Gerontol A Biol Sci Med Sci 55: B183-190. [Crossref]

51. Leelawattana R, Ziambaras K, Roodman-Weiss J, Lyss C, Wagner D, et al. (2000) The oxidative metabolism of estradiol conditions postmenopausal bone density and bone loss. J Bone Miner Res 15: 2513-2520. [Crossref]

52. Itoi H, Minakami H, Iwasaki R, Sato I (2000) Comparison of the long-term effects of oral estriol with the effects of conjugated estrogen on serum lipid profile in early menopausal women. Maturitas 36: 217-222. [Crossref]

53. Kano H, Hayashi T, Sumi D, Matusi-Hirai H, Tsunekawa T, et al. (2002) Estriol retards and stabilizes atherosclerosis through an NO-mediated system. Life Sci 71: 31-42. [Crossref]

54. Kurabayashi T, Okada M, Tanaka K (2000) Eicosapentaenoic acid effect on hyperlipidemia in menopausal Japanese women. The Niigata Epadel Study Group. Obstet Gynecol 96: 521-528. [Crossref]

55. Takahashi K, Manabe A, Okada M, Kurioka H, Kanasaki H, et al. (2000) Efficacy and safety of oral estriol for managing postmenopausal symptoms. Maturitas 34: 169-177. [Crossref]

56. Son DS, Roby KF, Rozman KK, Terranova PF (2002) Estradiol enhances and estriol inhibits the expression of CYP1A1 induced by 2,3,7,8-tetrachlorodibenzo-p-dioxin in a mouse ovarian cancer cell line. Toxicology 176: 229-243. [Crossref]

57. Lundstrom E, Wilczek B, von Palffy Z, Soderqvist G, von Schoultz B (2001) Mammographic breast density during hormone replacement therapy: effects of continuous combination, unopposed transdermal and low-potency estrogen regimens. Climacteric 4: 42-48. [Crossref]

58. Lyytinen H, Pukkala E, Ylikorkala O (2006) Breast cancer risk in postmenopausa women using estrogen-only therapy. Obstet Gynecol 108: 1354-1360. [Crossref]

59. Sicotte NL, Liva SM, Klutch R, Pfeiffer P, Bouvier S, et al. (2002) Treatment of multiple sclerosis with the pregnancy hormone estriol. Ann Neurol 52: 421-428. [Crossref]

60. Palaszynski KM, Liu H, Loo KK, Voskuhl RR (2004) Estriol treatment ameliorates disease in males with experimental autoimmune encephalomyelitis: implications for multiple sclerosis. J Neuroimmunol 149: 84-89. [Crossref]

61. Kim S, Liva SM, Dalal MA, Verity MA, Voskuhl RR (1999) Estriol ameliorates autoimmune demyelinating disease: implications for multiple sclerosis. Neurology 52 1230-1238. [Crossref]

62. Drew PD, Chavis JA (2000) Female sex steroids: effects upon microglial cell activation J Neuroimmunol 111: 77-85. [Crossref] 
63. Zang YC, Halder JB, Hong J, Rivera VM, Zhang JZ (2002) Regulatory effects of estriol on $\mathrm{T}$ cell migration and cytokine profile: inhibition of transcription factor NF-kappa B. J Neuroimmunol 124: 106-114. [Crossref]

64. Longcope C (1984) Estriol production and metabolism in normal women. J Steroid Biochem 20: 959-962. [Crossref]

65. Heine RP, McGregor JA, Dullien VK (1999) Accuracy of salivary estriol testing compared to traditional risk factor assessment in predicting preterm birth. Am J Obstet Gynecol 180: S214-218. [Crossref]
66. Kundu N, Novak N, Petersen LP (1983) Salivary unconjugated estriol levels in normal third trimester pregnancy-direct correlation with serum levels. Steroids 41: 145-153. [Crossref]

67. Fischer-Rasmussen W, Gabrielsen MV, Wisborg T (1981) Relation of estriol in saliva to serum estriol during normal pregnancy. Acta Obstet Gynecol Scand 60: 417-420. [Crossref]

68. Test ID: UE3. Estriol, Unconjugated, Serum. [http://www.mayomedicallaboratories com/test-catalog/Clinical+and+Interpretive/81711]

Copyright: (C2015 Falah N. This is an open-access article distributed under the terms of the Creative Commons Attribution License, which permits unrestricted use, distribution, and reproduction in any medium, provided the original author and source are credited. 